\title{
Improvement in Fear Memory by Histamine-Elicited ERK2 Activation in Hippocampal CA3 Cells
}

\author{
Maria Grazia Giovannini, ${ }^{1}$ Marcel Efoudebe, ${ }^{1}$ Maria Beatrice Passani, ${ }^{1}$ Elisabetta Baldi, ${ }^{2}$ Corrado Bucherelli, ${ }^{2}$ \\ Filippo Giachi, ${ }^{1}$ Renato Corradetti, ${ }^{1}$ and Patrizio Blandina ${ }^{1}$ \\ ${ }^{1}$ Dipartimento di Farmacologia Preclinica e Clinica, Universitá di Firenze, 50139 Firenze, Italy, and ${ }^{2}$ Dipartimento di Scienze Fisiologiche, Universitá di \\ Firenze, 50134 Firenze, Italy
}

\begin{abstract}
Consolidation of associative memories appears to require extracellular signal-related kinase2 (ERK2) activation, which is modulated by several factors, including neurotransmitter receptor stimulation. Here we show that in vitro stimulation of either $\mathrm{H}_{2}$ or $\mathrm{H}_{3}$ histaminergic receptors activates ERK2 in hippocampal CA3 pyramidal cells. In behaving animals, bilateral posttraining injections into the dorsal hippocampus of histamine $\mathrm{H}_{2}$ or $\mathrm{H}_{3}$ receptor agonists improve memory consolidation after contextual fear conditioning. Local administration of U0126, a selective inhibitor of ERK kinase, prevents memory improvements exerted by the agonists, without causing any behavioral effect per se. This is the first evidence of a positive correlation between ERK phosphorylation and memory improvement. Moreover, we demonstrate that the brain histaminergic system regulates hippocampal ERK cascade. Finally, our data indicate that early ERK2 hippocampal activation is not required for the expression of long-term fear memories.
\end{abstract}

Key words: contextual fear conditioning; ERK1; ERK2; hippocampus; histamine; $\mathrm{H}_{2}$ receptor; $\mathrm{H}_{3}$ receptor; U0126

\section{Introduction}

Enduring changes, such as a persistent increase in the strength of synaptic connections, occur in the CNS during memory consolidation as a result of transient experiences that, in the case of fearful events, are quickly acquired and consolidated into longterm memories. Most of what we know about fear memory comes from studies of fear conditioning, a paradigm that elicits robust associative learning, and comprises two components, a cued and a contextual one. Both components depend on the amygdala, whereas only the latter involves the hippocampus as well (Phillips and LeDoux, 1992; Sacchetti et al., 1999). Increasing evidence implicates extracellular signal-regulated kinase2 (ERK2) in fear-dependent neuronal plasticity (Schafe et al., 2001; Adams and Sweatt, 2002). Indeed, cued fear conditioning activated the ERK2 pathway in the amygdala, and local, posttraining infusion of U0126, an inhibitor of ERK2 phosphorylation, impaired long-term memory of this task (Schafe et al., 2000). ERK2 cascade was also transiently activated in the hippocampus $1 \mathrm{hr}$ after training with both cued and contextual fear conditioning (Atkins et al., 1998). Administration of ERK pathway inhibitors, such as SL327 (Atkins et al., 1998) or PD098059 (Schafe et al., 1999), impaired memory in both paradigms. However, SL327 was injected intraperitoneally, and PD098059 was injected intracerebroventricularly; therefore, the role of hippocampal ERK

Received Feb. 27, 2003; revised July 22, 2003; accepted July 31, 2003.

This research was supported by Ministero dell'Università e della Ricerca Scientifica e Tecnologica-Cofinanziamento grants and Fondazione Cassa di Risparmio di Firenze funds. We thank Dr. Annamaria Pugliese for preparing hippocampal slices used in the biochemical experiments. We thank Prof. Rob Leurs for the gift of amthamine and immepip, as well as Prof. Walter Schunack for providing methylhistaprodifen.

Correspondence should be addressed to Dr. Patrizio Blandina, Dipartimento di Farmacologia Preclinica e Clinica, Viale Gaetano. Pieraccini 6, 50139 Firenze, Italy. E-mail: patrizio.blandina@unifi.it.

Copyright @ 2003 Society for Neuroscience $\quad$ 0270-6474/03/239016-08\$15.00/0 phosphorylation remained undetermined. Upstream components of ERK pathway, such as neurotransmitters and neurotrophins, may act during the critical period of memory consolidation by modulating ERK activity, as suggested by NMDA receptor stimulation during fear conditioning (Atkins et al., 1998), or by nerve growth factor-induced effects during inhibitory avoidance (Walz et al., 2000a). A recent report demonstrated that histamine $\mathrm{H}_{3}$ receptors are coupled to the ERK signaling pathway in transfected COS-7 cells (Drutel et al., 2001). Histamine in the brain is released from varicosities of axons that ramify extensively throughout the CNS and originate within the only source of histaminergic fibers, the hypothalamic tuberomammillary nucleus (Panula et al., 1989). The histaminergic system is crucial in the sleep-wake cycle and is implicated in various brain functions, including the modulation of hippocampal synaptic plasticity (Brown et al., 2001; Haas and Panula, 2003). Interestingly, administration of $\mathrm{H}_{3}$ receptor antagonists into the amygdala impaired consolidation of fear memories (Passani et al., 2001), whereas that of $\mathrm{H}_{3}$ receptor agonists ameliorated the expression of adverse memories (Cangioli et al., 2002). This was accompanied by a bimodal modulation of the local cholinergic tone (Passani et al., 2001; Cangioli et al., 2002). We investigated the modulation of ERK phosphorylation by histamine and its role in fear memory consolidation in the hippocampus.

\section{Materials and Methods}

Animals

All experiments were performed on male Wistar rats (Harlan Italy, Udine, Italy), were done in strict compliance with the European Economic Community recommendations for the care and use of laboratory animals (86/609/CEE), and were approved by the Animal Care Committee of the Universitá di Firenze. 
Slice preparation for phosphorylated ERK determination

Male Wistar rats (150-180 gm) were anesthetized with ether and decapitated with a guillotine between 9:00 and 11:00 A.M. The brain was quickly removed and cooled in ice-cold oxygenated medium of the following composition (in $\mathrm{mm}$ ): $126 \mathrm{NaCl}, 1.5 \mathrm{KCl}, 1.25 \mathrm{KH}_{2} \mathrm{PO}_{4}, 26$ $\mathrm{NaHCO}_{3}, 1.5 \mathrm{MgSO}_{4}, 2 \mathrm{CaCl}_{2}$, and 10 D-glucose. The dorsal hippocampus was dissected and cut transversally into $350 \mu \mathrm{m}$ slices with a McIlwain (Gomshall, UK) tissue chopper. Slices were stabilized for $2 \mathrm{hr}$ at room temperature in the medium described above and bubbled with $95 \% \mathrm{O}_{2}-5 \% \mathrm{CO}_{2}, \mathrm{pH}$ 7.4. Each slice was then transferred to an incubation tube containing $1 \mathrm{ml}$ of the same oxygenated medium and kept in a water bath at $37^{\circ} \mathrm{C}$. After $60 \mathrm{~min}$, histamine or histamine agonists were added to the medium dissolved in volumes of $10 \mu$ l. Slices were incubated in the presence of the compound(s) under investigation for $5 \mathrm{~min}$. When the histamine receptor antagonists tetrodotoxin (TTX) or U0126 were used, slices were preincubated with the $\operatorname{drug}(\mathrm{s})$ for $5 \mathrm{~min}$ before the agonist was added. All incubations were performed at $37^{\circ} \mathrm{C}$. When drugs were dissolved in DMSO, proper controls were done to ensure that no vehicle effects were observed. At the end of the incubation time, each slice was collected from the incubation tube and treated for Western immunoblotting or immunohistochemistry. All slices used for subsequent immunoblotting or immunohistochemistry were harvested at least $3 \mathrm{hr}$ after slice preparation, when background phosphorylated ERK (p-ERK) levels are low (Winder et al., 1999). Each experiment included two control groups: unstimulated controls ("controls," harvested directly from the equilibration chamber) and sham-stimulated controls ("sham slices," placed in the incubation tube with no drug added).

\section{Immunohistochemistry}

Day 1. Immunohistochemistry was performed as described previously (Giovannini et al., 2001). After the end of stimulation, slices were immediately placed in wells of 24 -well plates containing $1 \mathrm{ml}$ of ice-cold $4 \%$ paraformaldehyde- $0.1 \%$ glutaraldehyde in PBS, $\mathrm{pH}$ 7.4, and fixed overnight. The slices were then washed for $2-3 \mathrm{hr}$ in PBS and sectioned into $40 \mu \mathrm{m}$ slices using a Vibratome (Lancer, Bridgeton, MO). Free-floating sections were rinsed for $10 \mathrm{~min}$ in PBS- $0.3 \%$ Triton X-100 (PBS-TX), incubated for $15 \mathrm{~min}$ in PBS-TX containing $0.75 \% \mathrm{H}_{2} \mathrm{O}_{2}$, rinsed three times with PBS-TX (10 min each), and blocked with $10 \%$ normal goat serum in PBS-TX (PBS-TX-NGS) for $40 \mathrm{~min}$. Sections were then incubated overnight at $4^{\circ} \mathrm{C}$ with rabbit primary polyclonal antibodies raised against phospho-(Thr202/Tyr204)-ERK (1:750; New England Biolabs, Beverly, MA).

Day 2. After washing in PBS-TX (three times, 10 min each), slices were incubated in biotinylated goat anti-rabbit secondary antibody (Vectastain; Vector Laboratories, Burlingame, CA) and diluted 1:200 in PBSTX-NGS for $2 \mathrm{hr}$ at room temperature. After washing the sections three times (10 min each) in PBS-TX, they were incubated for $90 \mathrm{~min}$ in avidin-biotin-peroxidase complex (final dilution of 1:100; Vectastain; Vector Laboratories). Sections were washed three times (10 min each) in PBS-TX, and staining was developed using a 3,3'-diaminobenzidine (DAB) staining kit (Vectastain; Vector Laboratories) with $\mathrm{NiCl}$ as enhancer. The reaction was developed for 2-3 min. After extensive washings, tissue sections were mounted onto gelatin-coated slides for light microscopic examination. Neurons of the CA3 pyramidal cell layer were counted in the region between the beginning of CA2 and the hilus, and an average of two to three slices was calculated. All counts were performed blind to the stimulating conditions of the slices. Images of DAB-stained slices were examined using an Olympus Optical (Milan, Italy) BX40 microscope and photographed using an Olympus Optical DP 50 digital camera, transformed into TIFF files, assembled into montages using Adobe Photoshop (Adobe Systems, Mountain View, CA) and Microsoft (Seattle, WA) PowerPoint, and printed using a HP DeskJet 970CX1 printer (Hewlett-Packard, Palo Alto, CA).

\section{Western immunoblotting}

Western immunoblotting was performed as described previously (Giovannini et al., 2001). Briefly, slices were immediately frozen on dry ice. The CA3 region was microdissected, transferred to ice-cold microcentrifuge tubes, and kept at $-20^{\circ} \mathrm{C}$ for no more than $3 \mathrm{~d}$ before assaying. Care was taken to ensure that the slices remained frozen throughout the procedure. Sham slices were removed at the corresponding time, whereas controls were harvested directly from the maintenance chamber. All Western analyses were performed blind to the tissue stimulation conditions. Seventy-five microliters of ice-cold lysis buffer were added to each tube, and tissues were homogenized on ice (a Potter-Elvehjem homogenizer) directly into the Eppendorf tube (15 strokes, 1 stroke/sec). The lysis buffer had the following composition: $50 \mathrm{~mm}$ Tris- $\mathrm{HCl}, \mathrm{pH}$ 7.5, 50 mм NaCl, 10 mм EGTA, 5 mм EDTA, 2 mм sodium pyrophosphate, 4 $\mathrm{mm}$ para-nitrophenylphosphate, $1 \mathrm{~mm}$ sodium orthovanadate, $1 \mathrm{~mm}$ phenylmethylsulfonyl fluoride (PMSF), $25 \mathrm{~mm}$ sodium fluoride, $2 \mathrm{~mm}$ DTT, $20 \mu \mathrm{g} / \mathrm{ml}$ leupeptin, and $4 \mu \mathrm{g} / \mathrm{ml}$ aprotinin. Immediately after homogenization, an additional $2.5 \mu \mathrm{l}$ of PMSF was added to each tube, and protein determination was performed using Bio-Rad (Hercules, CA) Protein Assay reagent. An appropriate volume of $6 \times$ loading buffer was added to the homogenates, and samples were boiled for $5 \mathrm{~min}$. Samples (50 $\mu \mathrm{g}$ of proteins per well) were loaded on a 10\% SDS-PAGE gel and resolved by standard electrophoresis. The proteins were then transferred electrophoretically onto nitrocellulose membrane (Hybond-C extra; Amersham Biosciences, Arlington Heights, IL) using a transfer tank kept at $4^{\circ} \mathrm{C}$, with typical parameters being overnight with a constant current of $10 \mathrm{~mA}$. Membranes were blocked for $1 \mathrm{hr}$ at room temperature with blocking buffer (BB) [5\% nonfat dry milk in PBS containing $0.05 \%$ Tween 20 (PBS-T) ] and then probed for $2 \mathrm{hr}$ at room temperature using primary antibody for phospho-(Thr202/Tyr204)-ERK (rabbit polyclonal, 1:2000; New England Biolabs). After washing in PBS-T (three washes, $15 \mathrm{~min}$ each), the membranes were incubated with horseradish peroxidase-conjugated anti-rabbit IgG (1:5000; Boehringer Mannheim, Indianapolis, IN), and proteins were visualized using chemiluminescence (Amersham Biosciences ECL Western Blotting Analysis System). Membranes were then stripped by strong agitation with $0.2 \mathrm{~N} \mathrm{NaOH}(15$ $\mathrm{min}$, room temperature), blocked in $\mathrm{BB}$ for $1 \mathrm{hr}$ at room temperature, probed for $2 \mathrm{hr}$ at room temperature using antibodies for total ERK (1:2000; New England Biolabs), incubated in secondary antibody, and developed as above. All primary antibodies were dissolved in BB, whereas secondary antibodies were dissolved in PBS-T. Densitometric analysis of the bands was performed by means of Scion (Frederick, MD) Image software. p-ERK values were normalized to total ERK, and values were expressed as the percentage relative to nonstimulated controls run in the same experiment. In no experiment did the sham-stimulated slices differ significantly from controls.

\section{Behavioral experiments}

Animals were trained and tested in a modified skinner box (Modular Operant Cage; Coulbourn Instruments, Allentown, PA), with top and two opposite sides made of aluminum panels, and the other two sides of transparent plastic. The floor was made of stainless steel rods connected to a shock delivery apparatus (Grid Floor Shocker, model E13-08; Coulbourn Instruments). The apparatus was placed in an acoustically insulated room kept at a constant temperature of $20 \pm 1^{\circ} \mathrm{C}$. Context freezing response was measured in the same apparatus that had been used for conditioning.

\section{Contextual fear conditioning procedure}

On day 1 , the rat was gently taken manually from the home cage, placed in a bucket, and carried from the housing room to the appropriate soundproofed room. Once there, it was placed inside the conditioning apparatus. The rat was left undisturbed for $3 \mathrm{~min}$. After this time, seven foot shocks $(1 \mathrm{~mA}, 1 \mathrm{sec})$ were delivered at $30 \mathrm{sec}$ intervals. Two minutes after the end of the stimulation pattern, the rats were brought back to their home cages.

\section{Conditioned freezing measurement}

Freezing is one of the behavioral manifestations of conditional fear and consists of the absence of voluntary movements. Freezing duration was measured $72 \mathrm{hr}$ after compounds or saline administration. Animals were again placed inside the conditioning apparatus and left there for $6 \mathrm{~min}$, during which no electrical stimulation was applied. Rats' behavior was recorded by means of a closed circuit television system. Freezing time was 
measured with a stopwatch by personnel blinded to experimental conditions. All behavioral tests were performed between 10:00 and 12:00 A.M.

\section{Rat locomotor and exploratory activity}

Immediately after the measurement of conditioned freezing, the rat was gently placed on a round table with a diameter of $1.5 \mathrm{~m}$, and its behavior was observed for $3 \mathrm{~min}$. Data from rats showing abnormal locomotor and exploratory activities, grooming, yawning, and rearing were not included ( 4 of 81 rats were discarded).

\section{Surgery and drug administration}

Immediately after training, the rats were anesthetized with ketamine (100 $\mathrm{mg} / \mathrm{kg}$, i.p.). Drugs were dissolved in physiological saline and injected into the dorsal hippocampus of rats restrained in a stereotaxic apparatus, according to the following coordinates (Paxinos and Watson, 1998): anteroposterior, -4.1 ; lateral, \pm 2.5 ; ventral, 3.2. The injection needle (outside diameter, $0.3 \mathrm{~mm}$ ) was connected with a short piece of polyethylene tubing to a Hamilton syringe that was fixed to an electrode holder. Solutions ( $1 \mu \mathrm{l} / \mathrm{side}$ ) were injected over a $1-2 \mathrm{~min}$ period, and the needle was left in place for another minute before withdrawing it. Control groups received bilateral injections of saline.

We reported previously that unoperated rats and ketamineanesthetized rats that received intracerebral saline injections exhibited similar freezing responses to context and acoustic conditioned stimuli (Sacchetti et al., 1999), thus suggesting that post-trial ketamine anesthesia and surgical manipulations do not interfere with some late stages of memory consolidation. Indeed, ketamine-anesthetized animals display frequency-specific receptive field plasticity induced by Pavlovian fear conditioning (Lennartz and Weinberger, 1992). Therefore, it is conceivable that the amnesic effects caused by histamine agonists are independent of ketamine-induced NMDA blocking action under our experimental conditions.

\section{Histology}

At the end of the experiments, rats were deeply anesthetized, and the brains were removed and stored in 10\% formaldehyde solution for $10 \mathrm{~d}$. Brain sections were cut with a freezing microtome and Nissl stained to verify the injection sites. If one or both needles were misplaced, the animals were discarded.

\section{Statistical analysis}

Summary data are presented as group means \pm SEM. Group means were analyzed using either Student's $t$ test or by ANOVA, followed by Newman-Keuls post hoc tests. For all statistical tests, $p<0.05$ was considered significant.

\section{Chemicals}

The substances used in this study include the following: $R-\alpha$ methylhistamine dihydrochloride (RAMH) (Research Biochemicals, Natick, MA), amthamine and immepip (kindly provided by Dr. R. Leurs, Vrije University, Amsterdam, The Netherlands), methylhistaprodifen (MHPN) (kindly provided by Dr. W. Schunack, Freie Universität Berlin, Berlin, Germany), tetrodotoxin (Sigma, St. Louis, MO), and U0126 (Tocris Cookson, Avonmouth, UK).

\section{Results \\ Effects of histamine or selective histamine receptor agonists on ERK activation on rat hippocampal slices}

Results of the immunohistochemistry are shown in Figure 1, in which representative photomicrographs of p-ERK labeling are presented in $a-j$, and counts of p-ERK-labeled cells are shown in $k$. Incubation for $5 \mathrm{~min}$ with $0.1 \mu \mathrm{M}$ histamine significantly increased p-ERK immunoreactivity compared with shams. The effect of histamine was mimicked by immepip $(0.01 \mu \mathrm{M})$, RAMH $(0.1 \mu \mathrm{M})$, both selective $\mathrm{H}_{3}$ receptor agonists, and amthamine $(0.1 \mu \mathrm{M})$, a selective $\mathrm{H}_{2}$ receptor agonist. Conversely, MHPN (1 $\mu \mathrm{M}$ ), a histamine $\mathrm{H}_{1}$ receptor agonist, failed to increase significantly p-ERK immunoreactivity compared with shams (Fig. 1k). It is noteworthy that p-ERK labeling was observed exclusively in pyramidal cells of the CA3 region in all experiments, regardless of the agonist used. At a higher magnification, it is clear that ERK activation occurred in both dendrites and cell bodies (Fig. 1h). ANOVA for the cell counts revealed an overall significant difference between groups $\left(F_{(5,44)}=18.99 ; p<0.0001\right)$, with a significant difference (Newman-Keuls multiple comparison test) between shams and histamine $(p<0.001)$, amthamine $(p<$ $0.001)$, immepip ( $p<0.001)$, or RAMH $(p<0.001)$ groups but not between shams and MHPN. The increase in p-ERK as assessed by immunohistochemistry was confirmed by Western blotting. Representative blots of sham and histamine-treated slices, as well as histograms, are shown in Figure 1l. Incubation of hippocampal slices with $0.1 \mu \mathrm{M}$ histamine for 5 min significantly increased immunoreactivity of p-ERK2, but not of p-ERK1, compared with sham (Student's $t$ test; $p<0.001$ ). The increase was not accounted for by changes in total ERK. Consistent with the immunohistochemistry results, Western blot analysis confirmed increases in p-ERK2 immunoreactivity in slices incubated for 5 min with either amthamine $(0.1 \mu \mathrm{M})$ or RAMH $(0.1 \mu \mathrm{M})$ compared with sham-operated animals. Representative blots of control and treated slices, as well as histograms, are shown in Figure 2. Increase was selective for p-ERK2, because p-ERK1 immunoreactivity was not significantly changed with different treatments. The increase could not be accounted for by changes in total ERK. ANOVA for p-ERK2 immunoreactivity revealed an overall significant difference between groups $\left(F_{(2,18)}=4.562 ; p<0.05\right)$, with a significant difference (Newman-Keuls multiple comparison test) between sham and both amthamine $(p<0.05)$ and RAMH $(p<0.05)$.

\section{Effects of selective histamine receptor antagonists}

To unequivocally confirm the involvement of histamine $\mathrm{H}_{2}$ and $\mathrm{H}_{3}$ receptors, we examined the effects of two histaminergic antagonists, zolantidine and thioperamide, at concentrations selective for the $\mathrm{H}_{2}$ and $\mathrm{H}_{3}$ receptors, respectively (Fig. 3). The slices were preincubated for $5 \mathrm{~min}$ in the presence of zolantidine ( 5 $\mu \mathrm{M})$, thioperamide $(100 \mathrm{nM})$, or their association. Then, amthamine $(0.1 \mu \mathrm{M})$, histamine $(0.1 \mu \mathrm{M})$, or immepip $(0.01 \mu \mathrm{M})$ were added to the medium for an additional $5 \mathrm{~min}$, whereas the antagonist(s) were maintained in the medium. ANOVA for p-ERK-labeled cells across drug treatments revealed a significant group effect (ANOVA; $\left.F_{(10,75)}=8.73 ; p<0.0001\right)$. The Newman-Keuls multiple comparison test confirmed the involvement of $\mathrm{H}_{2}$ and $\mathrm{H}_{3}$ receptors. Indeed, the number of p-ERK-labeled cells in amthamine-zolantidine- or immepip-thioperamidetreated slices was significantly lower compared with that in slices treated only with amthamine $(p<0.05)$ or immepip $(p<$ 0.001 ), respectively (Fig. 3). Interestingly, neither zolantidine nor thioperamide significantly antagonized the effect of histamine when added to the incubation medium separately. Conversely, when $\mathrm{H}_{2}$ and $\mathrm{H}_{3}$ receptors were blocked simultaneously by the combination of the two antagonists, the number of p-ERKlabeled cells was reduced significantly compared with histamine alone $(p<0.001)$ (Fig. 3). Zolantidine or thioperamide alone failed to influence ERK pathway activation compared with shams (Fig. 3).

\section{Tetrodotoxin sensitivity of histamine $\mathrm{H}_{2}$ or $\mathrm{H}_{3}$ receptor responses}

We attempted to elucidate the neural arrangement underlying histaminergic modulation, because histamine activated hippocampal ERK2 pathway through stimulation of both $\mathrm{H}_{3}$ and $\mathrm{H}_{2}$

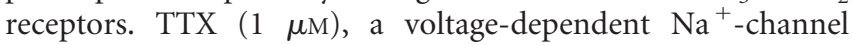


CONTROL
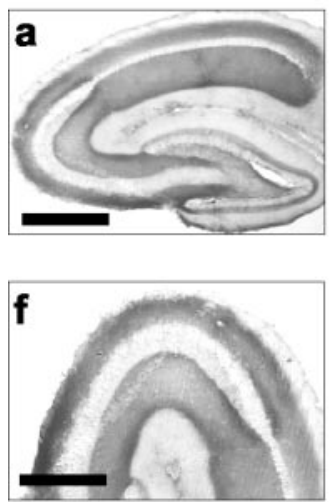

HISTAMINE
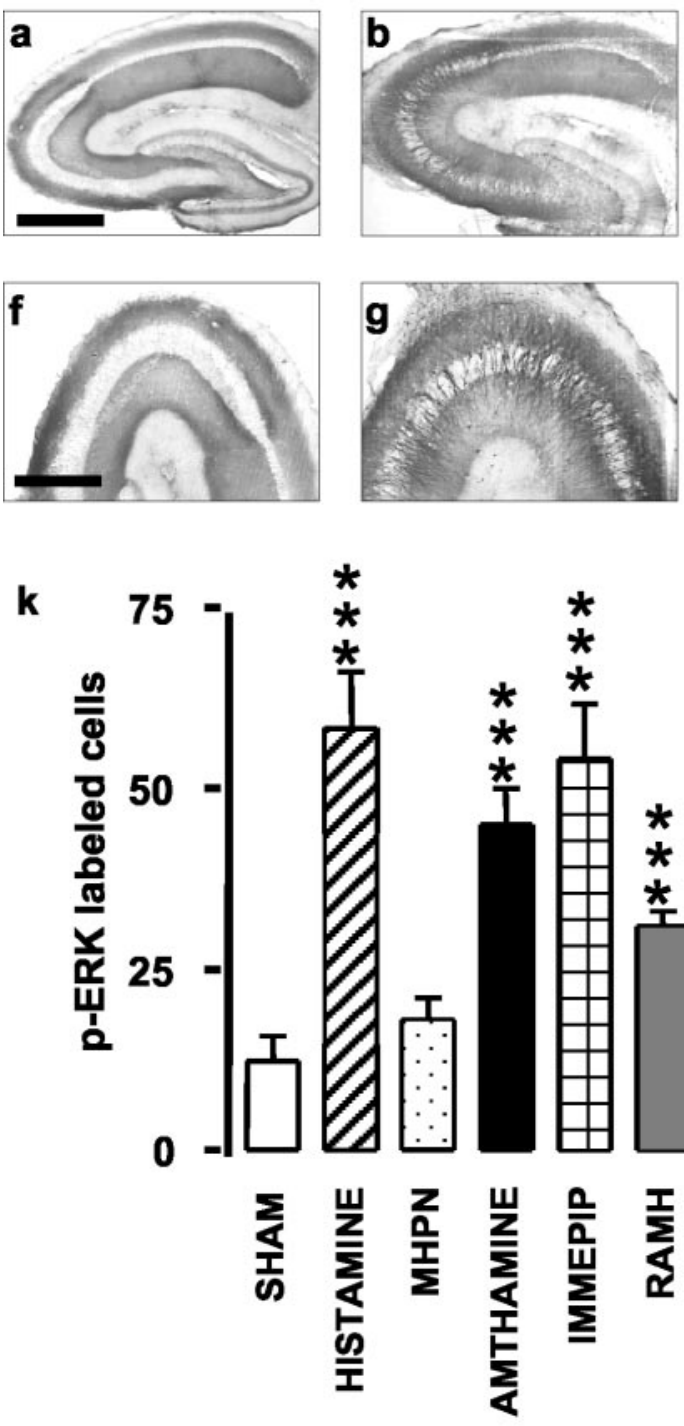

AMTHAMINE
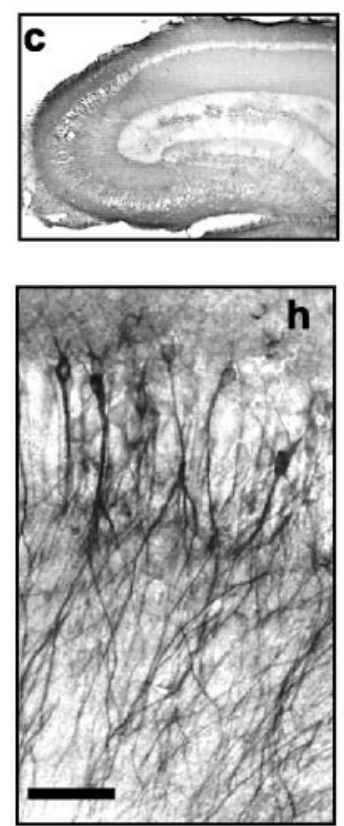

IMMEPIP
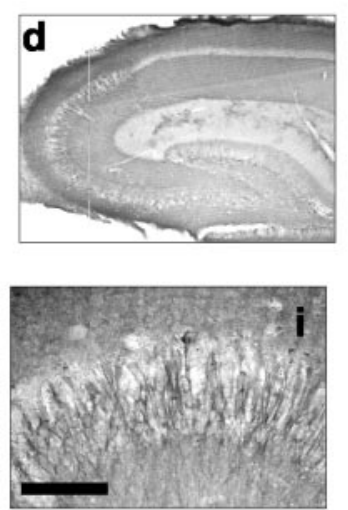

I

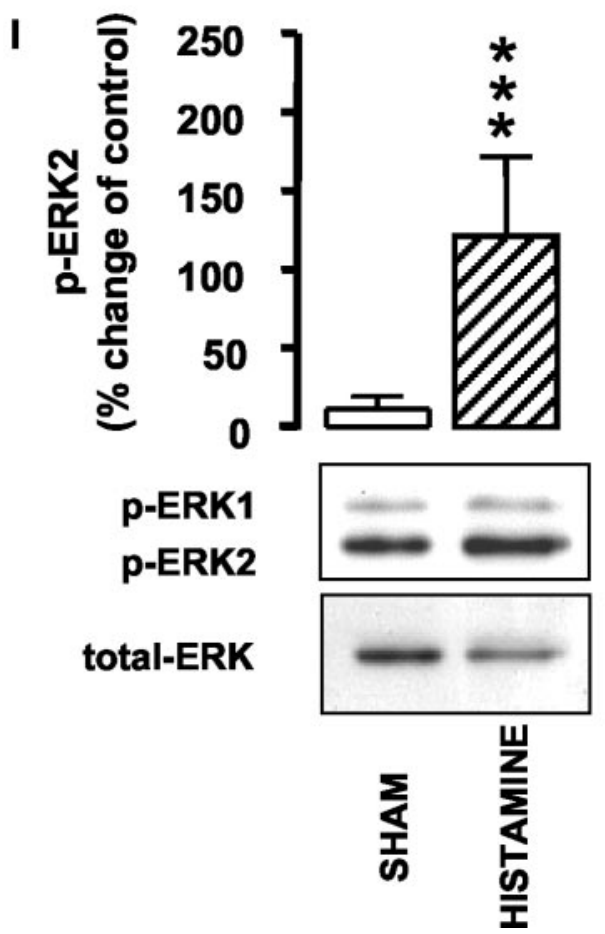

Figure 1. Histamine and histamine agonists activate ERK cascade in rat hippocampal slices. $a$-j, Representative photomicrographs for p-ERK immunoreactivity in hippocampal slices. Sections in the bottom row show corresponding CA3 regions at higher magnification. ERK activation occurred exclusively in both dendrites and cell bodies of CA3 pyramidal cells. Scale bars: $a-e, 1 \mathrm{~mm} ; f, g, j$, $750 \mu \mathrm{m} ; i, 200 \mu \mathrm{m} ; h, 75 \mu \mathrm{m}$. $k$, Summary histograms showing the number of neurons staining positive for $p$-ERK in shams $(n=9)$ and in slices treated with $0.1 \mu \mathrm{m}$ histamine $(n=4), 1 \mu \mathrm{m} \mathrm{MHPN}$ $(n=3), 0.1 \mu \mathrm{m}$ amthamine $(n=10), 0.01 \mu \mathrm{m}$ immepip $(n=3)$, and $0.1 \mu \mathrm{m}$ RAMH $(n=10)$. Shown are means \pm SEM. ${ }^{* * *} p<0.001$ versus sham (ANOVA and Newman-Keuls multiple comparison test). I, Densitometric analysis for p-ERK2 activation in sham $(n=11)$ and $0.1 \mu \mathrm{m}$ histamine-treated slices $(n=6)$; representative Western blots of $\mathrm{p}$-ERK immunoreactivity are displayed in the bottom panel. Increase was selective for $p$-ERK2, because $p$-ERK1 immunoreactivity was not significantly changed with different treatments. No changes in total ERK amount were observed. Shown are means \pm SEM. ${ }^{* * *} p<0.001$ versus sham (Student's $t$ test).

blocker, was equilibrated with the slice for $5 \mathrm{~min}$ before the addition of either amthamine $(0.1 \mu \mathrm{M})$ or RAMH $(0.1 \mu \mathrm{M})$. Under these conditions, amthamine-elicited activation of the ERK2 pathway was not affected, but the activation elicited by RAMH was abolished (Fig. 4). ANOVA of cell counts demonstrated an overall significant difference between groups $\left(F_{(5,66)}=8.257 ; p<\right.$ 0.0001 ), with a significant difference (Newman-Keuls multiple comparison test) between control and amthamine $(p<0.001)$, amthamine-TTX $(p<0.01)$, or RAMH $(p<0.05)$ but not between control and RAMH-TTX.

Effects of U0126 on histamine $\mathrm{H}_{2}$ or $\mathrm{H}_{3}$ receptor responses The MEK (mitogen-activated protein kinase kinase) inhibitor U0126 antagonized amthamine- and RAMH-elicited ERK phos- phorylation in the hippocampal slice. Slices were preincubated for $5 \mathrm{~min}$ in the presence of U0126 $(10 \mu \mathrm{M})$ before adding amthamine $(0.1 \mu \mathrm{M})$ or RAMH $(0.1 \mu \mathrm{M})$ to the incubation medium. Immunohistochemistry results are shown in Figure 5, in which representative photomicrographs of p-ERK labeling are presented in $a-f$. Clearly, no ERK activation occurred in slices preincubated with U0126 before the addition of either amthamine (Fig. $5 b-e$ ) or RAMH (Fig. $5 c-f$ ). Counts of p-ERKlabeled cells are shown in $g$. ANOVA for the cell counts found an overall significant difference between groups $\left(F_{(4,37)}=19.86 ; p<\right.$ 0.0001). Amthamine was significantly different from amthamine-U0126 ( $p<0.001)$, and RAMH was significantly different from RAMH-U0126 ( $p<0.001$; Newman-Keuls multiple comparison test). 


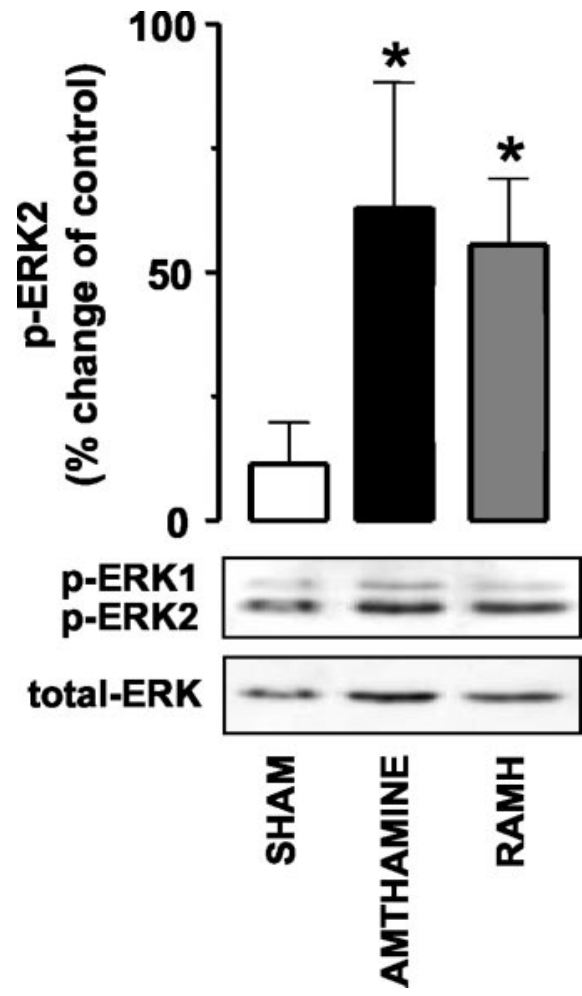

Figure 2. Amthamine and RAMH activate the ERK cascade in rat hippocampal slices. Densitometric analysis for p-ERK2 activation in shams $(n=11)$ and in $0.1 \mu \mathrm{m}$ amthamine-treated $(n=5)$ and $0.1 \mu \mathrm{M}$ RAMH-treated $(n=5)$ slices; representative Western blots of $p$-ERK immunoreactivity are displayed in the bottom panel. Increase was selective for $p$-ERK2, because p-ERK1 immunoreactivity was not significantly changed with different treatments. No changes in total ERK amount were observed. Shown are means \pm SEM. ${ }^{*} p<0.05$ versus sham (ANOVA and Newman-Keuls multiple comparison test).

Posttraining infusions of $\mathrm{H}_{2}$ or $\mathrm{H}_{3}$ receptor agonists into the hippocampus affect the expression of contextual fear memory Because activation of the ERK cascade appears to be relevant to consolidation of associative memories in the mammalian brain (Atkins et al., 1998), we next assessed whether its activation by histaminergic drugs influenced fear conditioning. The effects of amthamine and RAMH on contextual fear conditioning were observed in rats that had received posttraining, bilateral injections of these compounds into the hippocampus. Each drug was freshly diluted in saline to permit injection of a constant volume $(1 \mu \mathrm{l} /$ side). Rats that received bilateral intrahippocampal infusions of the histaminergic agonists failed to have modified behavior (locomotor and exploratory activities, grooming, yawning, and rearing) during the $3 \mathrm{~d}$ between training and testing. Rats that received bilateral intrahippocampal infusions of either amthamine or RAMH immediately after training showed a stronger response to the footshock-context association, as evidenced by the time spent freezing in the $72 \mathrm{hr}$ retention test (Fig. 6). The ANOVA on the freezing behavior revealed a significant treatment effect $\left(F_{(6,70)}=4.875 ; p<0.0003\right)$. Neuman-Keuls post hoc analysis showed that rats receiving either $1.25 \mathrm{ng}$ of RAMH or $0.16 \mathrm{ng}$ of amthamine spent significantly more time freezing than unoperated controls ( $p<0.05$ vs amthamine and RAMH) or salineinjected controls ( $p<0.05$ vs amthamine and RAMH). Unoperated controls underwent contextual fear conditioning without receiving either ketamine or saline injections. Blockade of ERK activation by local infusion of U0126 did not significantly alter freezing duration compared with controls (Fig. 6) but completely

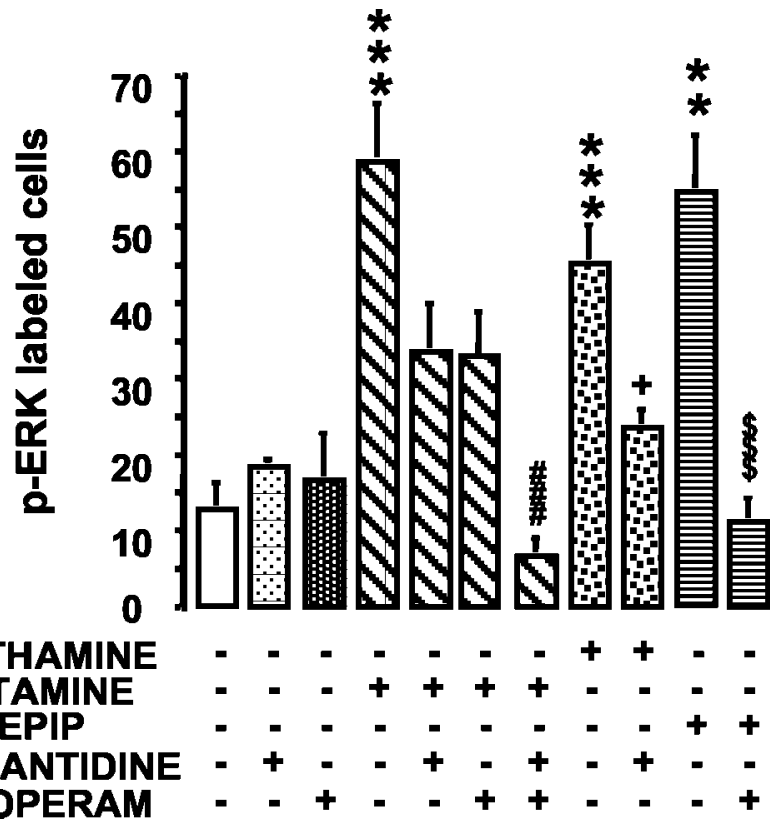

Figure 3. Influence of zolantidine and thioperamide (THIOPERAM) on histamine receptorelicited increase of $\mathrm{p}$-ERK immunoreactivity in hippocampal slices. Neurons staining positive for p-ERK in hippocampi of shams $(n=9), 5 \mu$ m zolantidine $(n=3), 100$ nm thioperamide $(n=$ 13), $0.1 \mu \mathrm{m}$ histamine $(n=4), 0.1 \mu \mathrm{m}$ histamine plus $5 \mu \mathrm{m}$ zolantidine $(n=5), 0.1 \mu \mathrm{M}$ histamine plus $100 \mathrm{~nm}$ thioperamide $(n=6), 0.1 \mu \mathrm{m}$ histamine plus $5 \mu \mathrm{m}$ zolantidine plus 100 nм thioperamide $(n=6), 0.1 \mu \mathrm{m}$ amthamine $(n=10), 0.1 \mu \mathrm{m}$ amthamine plus $5 \mu \mathrm{m}$ zolantidine $(n=6), 0.01 \mu \mathrm{m}$ immepip $(n=3)$, and $0.01 \mu \mathrm{m}$ immepip plus $100 \mathrm{~nm}$ thioperamide $(n=9)$. Shown are means \pm SEM. ${ }^{* *} p<0.01$ and ${ }^{* * *} p<0.001$ versus sham; \#\#\#p $<$ 0.001 versus $0.1 \mu \mathrm{m}$ histamine; $+p<0.05$ versus $0.1 \mu \mathrm{m}$ amthamine; $\$ \$ p<0.001$ versus 0.01 immepip (ANOVA and Newman-Keuls multiple comparison test).

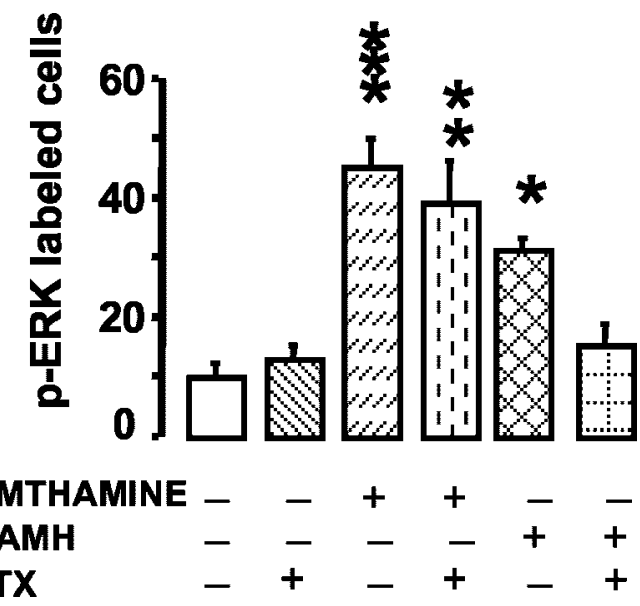

Figure 4. TTX sensitivity of amthamine- and RAMH-elicited increase of $p$-ERK immunoreactivity in hippocampal slices. Neurons staining positive for $p$-ERK in hippocampi of shams ( $n=$ 9), $0.1 \mu \mathrm{m}$ amthamine $(n=10), 0.1 \mu \mathrm{m}$ amthamine plus $1 \mu \mathrm{M} \mathrm{TTX}(n=16), 0.1 \mu \mathrm{M}$ RAMH $(n=10)$, and $0.1 \mu \mathrm{M}$ RAMH plus $1 \mu \mathrm{M}$ TTX $(n=8)$. Shown are means \pm SEM. ${ }^{*} p<0.05$, ${ }^{* *} p<0.01$, and ${ }^{* * *} p<0.001$ versus sham (ANOVA and Newman-Keuls multiple comparison test).

prevented the behavioral effects elicited by either amthamine ( $p<0.05$ vs amthamine alone) or RAMH ( $p<0.01$ vs RAMH alone) (Fig. 6). In these experiments, U0126 $(2 \mu \mathrm{g})$ was diluted in the same medium containing either amthamine or RAMH.

\section{Discussion}

Although the hippocampus receives only a moderate histaminergic innervation (Panula et al., 1989), histamine has many prom- 


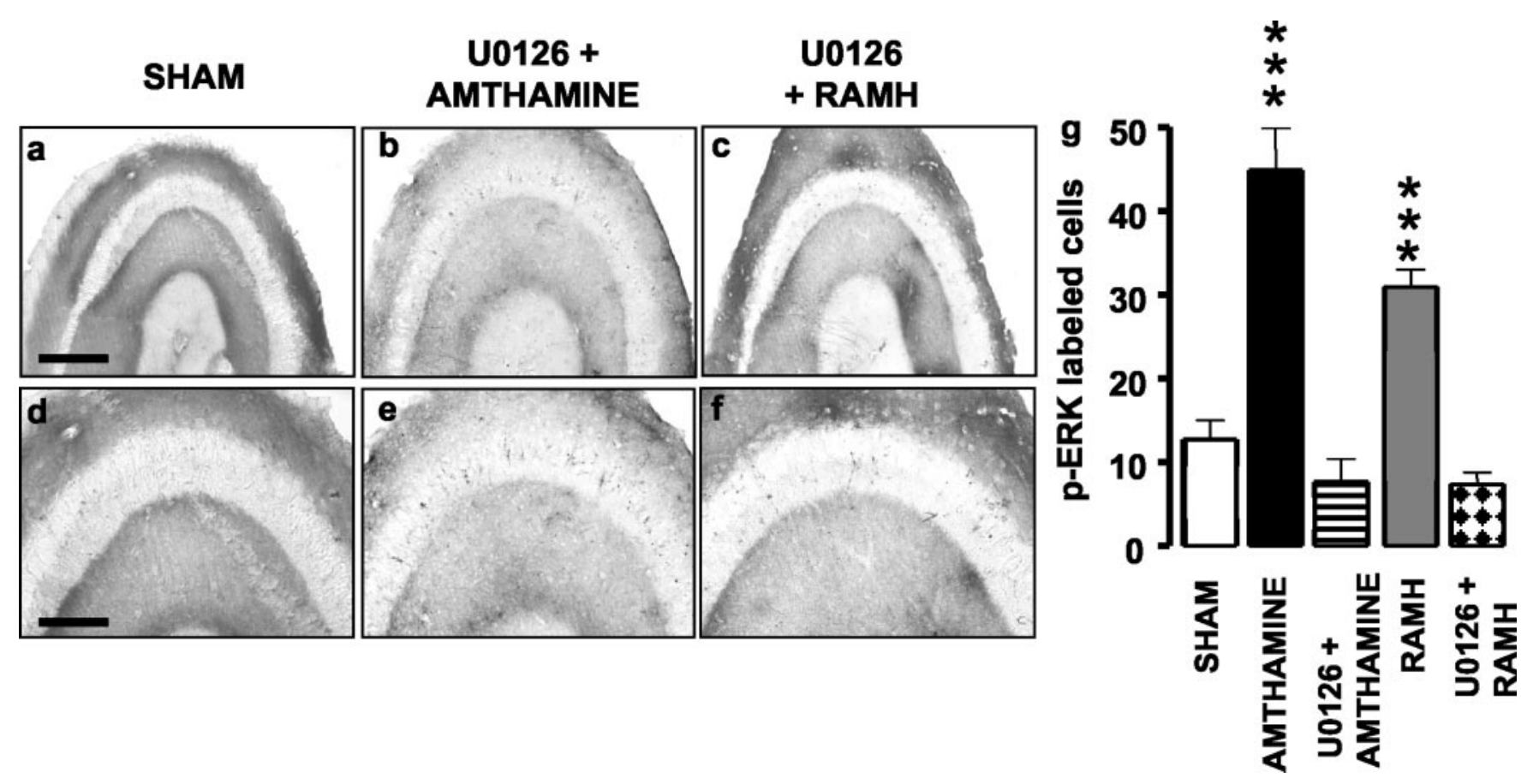

Figure 5. Influence of U0126 on amthamine- or RAMH-elicited increase of p-ERK immunoreactivity in hippocampal slices. $a-f$, Representative photomicrographs for $p$-ERK immunoreactivity in hippocampal slices. Scale bar: $a-c, 400 \mu \mathrm{m}, d-f, 200 \mu \mathrm{m} . g$, Summary histograms show the number of neurons staining positive for $p$-ERK in controls $(n=16)$, in slices treated with $0.1 \mu \mathrm{M}$ amthamine alone $(n=10)$ or associated with $2 \mu \mathrm{m}$ U0126 $(n=3)$, and $0.1 \mu \mathrm{M} \mathrm{RAMH} \mathrm{alone}(n=10)$ or associated with $2 \mu \mathrm{m}$ U0126 $(n=3)$. Shown are means \pm SEM. ${ }^{* * *} p<0.001$ versus control (ANOVA and Newman-Keuls multiple comparison test).

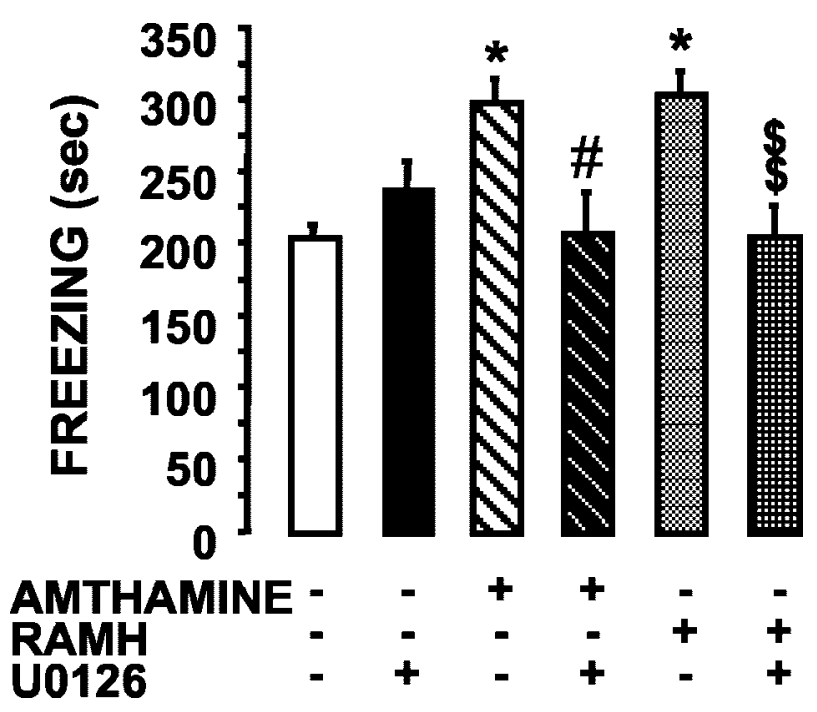

Figure 6. Effects on contextual fear conditioning of posttraining bilateral injection of amthamine, RAMH, and U0126 into the hippocampus. Immediately after training, rats were injected with $1 \mu \mathrm{l} /$ side under general anesthesia. One microliter of a $10 \mu \mathrm{m}$ solution of RAMH corresponded to a total amount of $1.25 \mathrm{ng}$, and $1 \mu \mathrm{l}$ of a $1 \mu \mathrm{m}$ solution of amthamine corresponded to $0.16 \mathrm{ng}$. Seventy-two hours after training, freezing was measured during the 6 min test period in unoperated controls $(n=10)$, saline-injected controls $(n=9)$, rats injected with $2 \mu \mathrm{g}$ of U0126 ( $n=12), 0.16 \mathrm{ng}$ of amthamine $(n=12), 0.16 \mathrm{ng}$ of amthamine plus $2 \mu \mathrm{g}$ of U0126 $(n=12), 1.25 \mathrm{ng}$ of RAMH $(n=10)$, and $1.25 \mathrm{ng}$ of RAMH plus $2 \mu \mathrm{g}$ of U0126 $(n=12)$. Shown are means \pm SEM. ${ }^{*} p<0.05$ versus unoperated and saline-injected control; $\# p<0.05$ versus amthamine; $\$ \$ p<0.01$ versus RAMH (ANOVA and Newman-Keuls multiple comparison test).

inent effects in this region (Atzori et al., 2000; Brown et al., 2001; Haas and Panula, 2003). The present demonstration (that stimulation of $\mathrm{H}_{2}$ and $\mathrm{H}_{3}$ receptors activate the ERK2 pathway in CA3 pyramidal cells in vitro and improve memory consolidation after contextual fear conditioning) provides major insight into histamine receptor regulation of hippocampal function and the physiological mechanisms underlying learning in the mammalian nervous system. $\mathrm{H}_{2}$ receptors are likely localized on CA3 pyramidal cells, because TTX insensitivity excludes the involvement of neuronal loops in the action of amthamine. This hypothesis is consistent with the report of $\mathrm{H}_{2}$ receptor-mediated excitatory actions of histamine observed with intracellular recordings in the CA3 region (Yanovsky and Haas, 1998). It should be noted that the pyramidal cell layer displays high $\mathrm{H}_{2}$ receptor gene transcripts (Vizuete et al., 1997). $\mathrm{H}_{2}$ receptor-mediated actions occur through stimulation of adenylyl cyclase and increased production of cAMP (Baudry et al., 1975). cAMP may activate protein kinase A (PKA), which phosphorylates cytosolic proteins (Sheng et al., 1991), including ERKs (Sweatt, 2001). Therefore, PKA may be the mechanism coupling the $\mathrm{H}_{2}$ receptor to ERK2 activation.

Conversely, the presence of TTX abolished RAMH-induced activation, strongly suggesting that $\mathrm{H}_{3}$ receptors are not located on the CA3 pyramidal cells or on nerve endings impinging on them. Thus, $\mathrm{H}_{3}$ receptors appear to be directly coupled to the ERK signaling pathway in transfected COS-7 cells (Drutel et al., 2001) but not in CA3 pyramidal neurons. In the simplest scenario, $\mathrm{H}_{3}$ receptors may promote the release of an, as yet, unidentified neurotransmitter, which in turn activates ERK cascade in CA3 pyramidal cells.

$\mathrm{H}_{3}$ receptors were initially detected as presynaptic autoreceptors inhibiting histamine release (Arrang et al., 1983) and, subsequently, were shown to also act as presynaptic heteroreceptors in non-histamine-containing neurons (Blandina et al., 1998). It is unlikely that $\mathrm{H}_{3}$ autoreceptors modulated ERK phosphorylation in the hippocampus, because antagonism of the $\mathrm{H}_{3}$ receptor by thioperamide, which should have increased endogenous histamine release, had no effect. Consistently, $\mathrm{H}_{3}$ receptor binding was not strictly associated with the presence of histaminergic fibers in 
the rat hippocampus (Pollard et al., 1993). Several neurotransmitters, such as dopamine, glutamate, and norepinephrine, activate the ERK cascade in the hippocampus (Adams and Sweatt, 2002), and histamine may interact with these neurotransmitters to orchestrate ERK2 phosphorylation in CA3 pyramidal cells. These neurons presumably mediate the information flow between cortical or subcortical structures and the CA1 area. Their integrity may be necessary for memory retention, because transection of longitudinally oriented axon collaterals of CA3 pyramidal cells impaired the retention of spatial memory (Steffenach et al., 2002).

ERK activation seems to be a requirement for $\mathrm{H}_{2}-$ or $\mathrm{H}_{3}$ induced memory improvement, because local administration of a selective inhibitor of MEK, U0126, abolished the freezing increase during recall in rats treated with either amthamine or RAMH. Accordingly, we demonstrated that U0126 antagonized amthamine- and RAMH-elicited ERK2 activation in rat hippocampal slices as well. Of the two isoforms, ERK1 and ERK2, only ERK2 is phosphorylated by either $\mathrm{H}_{2}$ or $\mathrm{H}_{3}$ receptor activation. Interestingly, hippocampus- and amygdala-dependent emotional memory does not depend critically on ERK1 activity, because mice lacking this isoform are unimpaired in emotional learning (Selcher et al., 2001). A critical role of ERK activation in consolidating declarative, spatial and emotional memories is clearly indicated by recent findings that demonstrate that either systemic or intracerebroventricular posttraining administration of ERK inhibitors cause loss of memory in subsequent recall tests (Adams and Sweatt, 2002) and that memory recall critically depends on the hippocampal CA3 region (Nakazawa et al., 2002). However, the report that U0126, administered immediately after training, has no behavioral effects indicates that early activation of ERK2 in the hippocampus is not necessary for the expression of long-term memory induced by contextual fear conditioning. These results are consistent with previous findings demonstrating that, in the same learning paradigm, ERK2 activation increases significantly only $1 \mathrm{hr}$ after training (Atkins et al., 1998). Walz et al. (1999, 2000b) observed a time-dependent involvement of ERK phosphorylation in the step-down inhibitory avoidance, a learning paradigm similar to associative fear conditioning (Sweatt, 2001). Rats were trained and tested in the inhibitory avoidance test and given an intrahippocampal infusion of PD098059 0, 30, 90, 120, 180, 270, or 360 min after training. A retention test session was performed $24 \mathrm{hr}$ after training. Intrahippocampal PD098059 impaired memory only when infused $180 \mathrm{~min}$ after training. However, other hippocampal mechanisms cannot be excluded, because early TTX injections into the dorsal hippocampus disrupted consolidation in fear conditioning (Sacchetti et al., 1999). The present findings suggest that histamine receptor stimulation might anticipate ERK2 phosphorylation and that this early activation improves memory consolidation.

Although several questions remain to be answered, our findings may help elucidate the components underlying fear conditioning. Increasing the ERK2 signal in CA3 pyramidal cells may strengthen contextual fear memories. This is the first evidence of a positive correlation between ERK2 activation and memory improvement and of the role of histamine as an upstream regulator of ERK2 phosphorylation. It has been proposed that brain histamine is a danger response signal, triggered by a variety of aversive stimuli such as stress, dehydration, and hypoglycemia (Brown et al., 2001), and experimental evidence suggests a role for CA3 pyramidal cells in stress-mediated effects on memory (Roozendaal et al., 2001). The histaminergic system may mediate the hypothalamic influences on hippocampal functions to achieve an adequate behavioral response (Haas and Panula, 2003 ) through neural circuits activated by emotional arousal and involving transmitters and intracellular events that have been only partly unraveled. Disturbances of brain mechanisms underlying emotional memory formation may contribute to mood disorders such as panic attacks, specific phobias, and generalized anxiety (Schneider et al., 1999; Emery and Amaral, 2000). The present study may contribute to the development of new strategies for the treatment of these disorders.

\section{References}

Adams JP, Sweatt JD (2002) Molecular physiology: roles for the ERK MAP kinase cascade in memory. Annu Rev Pharmacol Toxicol 42:135-163.

Arrang JM, Garbarg M, Schwartz J-C (1983) Auto-inhibition of brain histamine release mediated by a novel class $\left(\mathrm{H}_{3}\right)$ of histamine receptors. Nature 302:832-837.

Atkins CM, Selcher JC, Petraitis JJ, Trzaskos JM, Sweatt JD (1998) The MAPK cascade is required for mammalian associative learning. Nat Neurosci 1:602-609.

Atzori M, Lau D, Tansey EP, Chow A, Ozaita A, Rudy B, McBain CJ (2000) $\mathrm{H}_{2}$ histamine receptor-phosphorylation of Kv3.2 modulates interneuron fast spiking. Nat Neurosci 3:791-798.

Baudry M, Martres MP, Schwartz J-C (1975) $\mathrm{H}_{1}$ and $\mathrm{H}_{2}$ receptors in the histamine-induced accumulation of cyclic AMP in guinea-pig brain slices. Nature 253:362-364.

Blandina P, Bacciottini L, Giovannini MG, Mannaioni PF (1998) $\mathrm{H}_{3}$ modulation of the release of neurotransmitters in vivo. In: The histamine $\mathrm{H}_{3}$ receptor a target for new drugs (Leurs R, Timmerman H, eds), pp 27-40. Amsterdam: Elsevier.

Brown RE, Stevens DR, Haas HL (2001) The physiology of brain histamine. Prog Neurobiol 63:637-672.

Cangioli I, Baldi E, Mannaioni PF, Bucherelli C, Blandina P, Passani MB (2002) Activation of histaminergic $\mathrm{H} 3$ receptors in the rat basolateral amygdala improves expression of fear memory and enhances acetylcholine release. Eur J Neurosci 16:521-528.

Drutel G, Peitsaro N, Karlstedt K, Wieland K, Smit M, Timmerman H, Panula $\mathrm{P}$, Leurs R (2001) Identification of rat $\mathrm{H} 3$ receptor isoforms with different brain expression and signaling properties. Mol Pharmacol 59:1-8.

Emery NJ, Amaral DG (2000) The role of the amygdala in primate social cognition. In: Cognitive neuroscience of emotion (Lane RD, Nadel L, eds), pp 156-191. New York: Oxford UP.

Giovannini MG, Blitzer RD, Wong T, Asoma K, Tsokas P, Morrison JH, Iyengar R, Landau EM (2001) Mitogen-activated protein kinase regulates early phosphorylation and delayed expression of $\mathrm{Ca}^{2+} /$ calmodulindependent protein kinase II in long-term potentiation. J Neurosci 21:7053-7062.

Haas HL, Panula P (2003) The role of histamine and the tuberomamillary nucleus in the nervous system. Nat Neurosci Rev 4:121-130.

Lennartz R, Weinberger N (1992) Frequency-specific receptive field plasticity in the medial geniculate body induced by pavlovian fear conditioning is expressed in the anesthetized brain. Behav Neurosci 106:484-497.

Nakazawa K, Quirk MC, Chitwood RA, Watanabe M, Yeckel MF, Sun LD, Kato A, Carr CA, Johnston D, Wilson MA, Tonegawa S (2002) Requirement for hippocampal CA3 NMDA receptors in associative memory recall. Science 297:211-218.

Panula P, Pirvola U, Auvinen S, Airaksinen MN (1989) Histamineimmunoreactive nerve fibers in the rat brain. Neuroscience 28:585-610.

Passani MB, Cangioli I, Baldi E, Bucherelli C, Mannaioni PF, Blandina P (2001) Histamine $\mathrm{H}_{3}$ receptor-mediated impairment of contextual fear conditioning, and in-vivo inhibition of cholinergic transmission in the rat basolateral amygdala. Eur J Neurosci 14:1522-1532.

Paxinos G, Watson C (1998) The rat brain in stereotaxic coordinates. New York: Academic.

Phillips RG, LeDoux JE (1992) Differential contribution of amygdala and hippocampus to cued and contextual fear conditioning. Behav Neurosci 106:274-285

Pollard H, Moreau J, Arrang JM, Schwartz J-C (1993) A detailed autoradiographic mapping of histamine $\mathrm{H}_{3}$ receptors in rat brain areas. Neuroscience 52:169-189.

Roozendaal B, Phillips R, Power A, Brooke S, Sapolsky R, McGaugh JL 
(2001) Memory retrieval impairment induced by hippocampal CA3 lesions is blocked by adrenocortical suppression. Nat Neurosci 4:1169-1171.

Sacchetti B, Ambrogi Lorenzini C, Baldi E, Tassoni G, Bucherelli C (1999) Auditory thalamus, dorsal hippocampus, basolateral amygdala, and perirhinal cortex role in the consolidation of conditioned freezing to context and to acoustic conditioned stimulus in the rat. J Neurosci 19:9570-9578.

Schafe GE, Nadel N, Sullivan G, Harris A, LeDoux JE (1999) Memory consolidation for contextual and auditory fear memory is dependent on protein synthesis. Learn Mem 6:97-110.

Schafe GE, Atkins CM, Swank MW, Bauer EP, Sweatt JD, LeDoux JE (2000) Activation of ERK/MAP kinase is required for memory consolidation of pavlovian fear conditioning. J Neurosci 20:8177-8187.

Schafe GE, Nader K, Blair HT, LeDoux JE (2001) Memory consolidation of Pavlovian fear conditioning: a cellular and molecular perspective. Trends Neurosci 24:540-546.

Schneider F, Weiss U, Kessler C, Muller-Gartner HW, Posse S, Salloum JB, Grodd W, Himmelmann F, Gaebel W, Birbaumer N (1999) Subcortical correlates of differential classical conditioning of aversive emotional reactions in social phobia. Biol Psychiatry 45:863-871.

Selcher JC, Nekrasova T, Paylor R, Landreth GE, Sweatt JD (2001) Mice lacking the ERK1 isoform of MAP kinase are unimpaired in emotional learning. Learn Mem 8:11-19.

Sheng M, Thompson MA, Greenberg ME (1991) CREB: a $\mathrm{Ca}^{2+}$-regulated transcription factor phosphorylated by calmodulin-dependent kinases. Science 252:1427-1430.

Steffenach H-A, Sloviter RS, Moser EI, Moser M-B (2002) Impaired retention of spatial memory after transection of longitudinal oriented axons of hippocampal CA3 pyramidal cells. Proc Natl Acad Sci USA 99:3194-3198.
Sweatt JD (2001) The neuronal MAP kinase cascade: a biochemical signal integration system subserving synaptic plasticity and memory. J Neurochem 76:1-10.

Vizuete ML, Traiffort E, Bouthenet ML, Ruat M, Souil E, Tardivel-Lacombe J, Schwartz J-C (1997) Detailed mapping of the histamine $\mathrm{H}_{2}$ receptor and its gene transcripts in guinea-pig brain. Neuroscience 80:321-343.

Walz R, Roesler R, Barros DM, De Souza MM, Rodrigues C, Sant'Anna MK, Quevedo J, Choi HK, Neto WP, De David e Silva TL, Medina JH, Izquierdo I (1999) Effects of post-training infusions of a mitogen-activated protein kinase inhibitor into the hippocampus or entorhinal cortex on short- and long-term retention of inhibitory avoidance. Behav Pharmacol 10:723-730.

Walz R, Lenz G, Roesler R, Vianna M, Martins V, Brentani R, Rodnight R, Izquierdo I (2000a) Time-dependent enhancement of inhibitory avoidance retention and MAPK activation by post-training infusion of nerve growth factor into CA1 region of hippocampus of adult rats. Eur J Neurosci 12:2185-2189.

Walz R, Roesler R, Quevedo J, Sant'Anna MK, Madruga M, Rodrigues C, Gottfried C, Medina JH, Izquierdo I (2000b) Time-dependent impairment of inhibitory avoidance retention by post-training infusions of a mitogen-activated protein kinase inhibitor into cortical and limbic structures. Neurobiol Learn Mem 73:11-20.

Winder DG, Martin KC, Muzzio IA, Rohrer D, Chruscinski A, Kobilka B, Kandel ER (1999) ERK plays a regulatory role in induction of LTP by theta frequency stimulation and its modulation by beta-adrenergic receptors. Neuron 24:715-726.

Yanovsky Y, Haas HL (1998) Histamine increases the bursting activity of pyramidal cells in the CA3 region of mouse hippocampus. Neurosci Lett 240:110-112. 